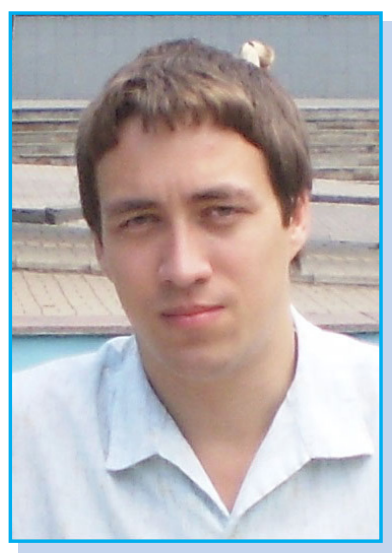

Ярослав Слуцький - кандидат педагогічних наук, викладач циклової комісії гуманітарних дисциплін, Донбаський державний коледж технологій та управління, м. Торецьк, докторант ДВНЗ «Донбаський державний педагогічний університет», м. Слов'янськ Коло наукових інтересів: соціально-педагогічний супровід іноземних студентів, технології медіаосвіти, розвиток соціально-освітньої інфраструктури, волонтерська діяльність.

yaroslav.slutskiy.mail@gmail.com

https://orcid.org/0000-0002-5328-7274

УДК 378.013.42:378.091-054.6-057.875(477)

https://doi.org/10.32405/2411-1317-2021-3-24-34

\title{
ПЕРСПЕКТИВНІ НАПРЯМИ РОЗВИТКУ АДАПТАЦИЙНОЇ СИСТЕМИ ПІДГОТОВКИ ІНОЗЕМНИХ СТУДЕНТІВ В УКРАЇНСЬКИХ ЗАКЛАДАХ ВИЩОЇ ОСВІТИ
}

У статті досліджено сучасний стан і визначено перспективні напрями розвитку адаптаційної системи підготовки іноземних студентів у закладах вищої освіти України. Виокремлено організаційний та адаптаційно-освітній елементи адаптації. Увага приділена перспективним напрямам організаційного елементу, серед яких: створення центрів підготовки іноземних студентів на базі 3ВО, які мають виконувати координацію адаптаційних програм і надавати консультаційну допомогу, що дасть змогу повноцінно розвивати навички акультураційної тріади; а також організацій міжнародного напряму для роботи з іноземними студентами, що сприятиме розвитку вітчизняної освітньої системи та підвищенню потенціалу закладів вищої освіти в проведенні адаптаційної підготовки. Використана порівняльна характеристика українських та американських ЗВО в питанні проведення адаптаційних заходів, що дало змогу виокремити перспективні напрями, які потребують активного впровадження у систему підготовки іноземних студентів вітчизняних закладів освіти.

Ключові слова: дослідницько-аналітична діяльність; організаторсько-консультаційні функції; акультураційна діада / тріада; соціально-педагогічний супровід.

Постановка проблеми. Сучасна система освіти повинна трансформуватися відповідно до глобальних змін соціуму, що викликає ефект «інтернаціоналізації освіти». Одним із проявів такого ефекту є збільшення кількості іноземних студентів, що потребує наявності у навчального закладу відповідної бази, яка забезпечить підготовку за всіма елементами акультураційної тріади, серед яких: лінгвістичний, освітньо-культурний і психологічний. Саме означена тріада, при одночасному застосуванні всіх елементів під час адаптаційного процесу, дозволяє подолати негативні наслідки культурного шоку i, таким чином, забезпечити якісну діяльність студента в академічній і соціальній площинах.

Відповідно, для визначення характеристик та особливостей наявних підготовчих програм українських $3 В 0$ і окреслення перспективних напрямів, що вимагають подальшого вдосконалення та модернізації, необхідно провести порівняння адаптаційної роботи вітчизня- 
них закладів освіти з найбільш ефективними зарубіжними прикладами. У зв’язку з тим, що Сполучені Штати Америки приймають найбільшу кількість іноземних студентів серед усіх країн світу [1], вважаємо за необхідне посилатися саме на цю державу при здійсненні порівняльної характеристики.

Аналіз останніх досліджень і публікацій. Важливо відзначити, що умовою якісно побудованої системи адаптаційної підготовки іноземних студентів $є$ наявність повноцінної нормативно-правової бази, яка б регулювала організаційний процес. Тому варто відзначити наявність досліджень у цій сфері; наприклад, Ч. Хаддал [2] досліджував законодавчу базу освітньої підготовки іноземних студентів у США, безпосередньо підготовчий процес, що має базуватися на інтернаціоналізації навчального плану, бути індивідуальним і перспективним, вивчали В. Кліффорд та К. Монтгомері [3]. Окрім нормативно-правових та організаційних елементів, адаптаційний процес повинен забезпечуватися спеціалізованими посібниками для іноземних студентів. Прикладом може слугувати розроблене такими дослідниками, як С. Бердан, А. Гудман та К. Тейлор [4] керівництво для іноземних студентів. Проблеми, пов'язані безпосередньо з процесом інтернаціоналізації (Н. Харрісон [5]) і подолання стресових наслідків культурного шоку для представників різних національностей (С. Фаліл, К. Тем, Т. Лі, У. Гар [6]), також ставали предметом наукових розвідок. Вітчизняні дослідники активно вивчали питання адаптаційної підготовки іноземних студентів. Так, необхідно виділити роботи О. Білик [7], [8] (методики адаптації іноземних студентів у простір 3ВО, що має незнайомі освітньо-культурні характеристики), Л. Гармаш [9] (роль інтелектуального потенціалу студентів першого року навчання в академічній адаптації, що також актуально для «місцевих» студентів), В. Коломієць [10] (практичне застосування дидактичних ігор для формування лінгвістичних навичок у іноземних студентів), М. Максимець [11] (взаємозв’язок між вивченням іноземної мови і формуванням соціокультурних навичок) та ін.

Однак, активний розвиток глобалізаційних процесів (навіть не зважаючи на карантинні обмеження, пов'язані з пандемією COVID-19) вимагає проведення компаративістських досліджень, що дозволять визначити перспективні напрями розвитку вітчизняної адаптаційної системи.

Мета статті - проаналізувати сучасний стан української системи адаптаційної підготовки іноземних студентів і виявити перспективні напрями її розвитку.

Виклад основного матеріалу. Для дослідження розвитку напрямів адаптаційної системи в закладах вищої освіти України, нами були обрані певні університети. Критеріями їх вибору служили такі компоненти, як:

1) географічний - сприяв відбору закладів освіти з різних регіонів країни, що дозволило оцінити рівень розвиненості в них системи підготовки іноземних студентів;

2) кількісний - що був застосований для вибору Харківського національного університету ім. В.Н. Каразіна у зв’язку з тим, що саме цей заклад освіти проводить підготовку найбільшої кількості іноземних студентів у порівнянні з іншими ЗВО України (згідно з даними Українського державного центру міжнародної освіти [12]);

3) інформаційний - дав змогу виявити заклади освіти, сайти яких надають повну або недостатню інформаційну складову у питаннях адаптаційної підготовки іноземних студентів. Окрім того, можливість отримання такої інформації у віддаленому форматі особливо важлива у зв'язку з карантинними обмеженнями, що діють з весни 2020 року.

3 огляду на зазначені критерії, нами було обрано такі заклади вищої освіти для проведення дослідження: Харківський національний університет ім. В.Н. Каразіна (м. Харків), Полтавський державний аграрний університет (м. Полтава), Кременчуцький національний університет ім. Михайла Остроградського (м. Кременчук), Мукачівський державний університет (м. Мукачево), Тернопільський національний економічний університет (м Тернопіль), Національний педагогічний університет ім. М. П. Драгоманова (м. Київ), Дрогобицький державний педагогічний університет ім. Івана Франка (м. Дрогобич), Центральноукраїнський 
державний педагогічний університет ім. Володимира Винниченка (м. Кропивницький), Запорізький національний університет (м. Запоріжжя).

Аналіз відібраних 3ВО також потребував наявності критеріїв, згідно з якими досліджувалася ефективність того чи того університету. Такими критеріями були:

- наявність на сайтах закладів освіти достатньої інформації у відкритому доступі щодо стратегії адаптаційної підготовки іноземних студентів, включаючи освітній, нормативно-правовий та інші компоненти;

- застосування в навчальних закладах усіх елементів акультураційної тріади, що складається з лінгвістичної, освітньо-культурної та психологічної підтримки;

- наявність або відсутність програм підготовки іноземних студентів у відкритому доступі для виявлення рівня загальної та професійно спрямованої підготовки, що надається іноземним студентам.

Нормативно-правова база вибудовує тільки перший шар основи системи супроводу. Важливою складовою, яка безпосередньо впливає на розвиток та вдосконалення принципів роботи з іноземними студентами, є діяльність міжнародних організацій, що сприяють упровадженню нового досвіду адаптації іноземних студентів. Унаслідок порівняння українських організацій, спрямованих на підтримку іноземних студентів (наприклад, Український державний центр міжнародної освіти [13], Навчально-науковий інститут міжнародної освіти [14] тощо) з американськими, можемо зробити висновок про більш розвинену систему діяльності таких організацій саме у США. Природно, одним із факторів, який впливає на системність у розвитку міжнародно-спрямованих організацій, є час, а саме розвиток таких ініціатив у Сполучених Штатах ще з початку XX століття. Прикладом може служити Інститут міжнародної освіти США [15], заснований у 1919 році. Діяльність цього закладу спрямована на підтримку та консультування іноземних студентів, а також проведення дослідницько-аналітичної діяльності (наприклад, презентація щорічних звітів, на підставі яких можна вибудовувати подальшу стратегію адаптаційних дій).

Тому перспективним напрямом розвитку української консультаційної системи роботи з іноземними студентами є створення єдиного центру, який буде мати можливість проведення не тільки координації підготовчих програм 3ВО, але і виконуватиме дослідницькі функції, результати яких згодом повинні стати базою вивчення українських учених-теоретиків. У такому випадку ми зможемо говорити про системність процесу підтримки іноземних студентів. Враховуючи необхідність достатнього рівня самостійності, якою повинні володіти навчальні заклади, координаційний та науковий центр дозволить вибудувати єдину систему соціально-педагогічного супроводу для всіх 3ВО (натомість розрізнене розуміння адаптаційних дій університетами, коледжами, академіями та іншими закладами освіти України призведе до розбалансування адаптаційної системи та негативно позначиться на її цілісності).

Ще одним фактором, який суттєво впливає на систему адаптації іноземних студентів, $є$ Центри консультування, що створюються навчальними закладами як структурні підрозділи, метою яких є реалізація організаторсько-консультаційних функцій, а також проведення лінгвістичної, культурної та психологічної підтримки іноземних студентів перед вступом до ЗВО або під час першого року навчання, який найбільш впливає на особистість студента проявами культурного шоку.

Проведений нами аналіз підготовчої роботи з іноземними студентами в українських ЗВО (як-от Харківський національний університет ім. В.Н. Каразіна, Полтавський державний аграрний університет, Кременчуцький національний університет ім. Михайла Остроградського) демонструє не тільки наявність таких центрів, але і впровадження до їх планів роботи методів, що використовуються в американських університетах та коледжах. Цьому сприяє зазначена у положеннях про роботу цих центрів вимога щодо моніторингу зарубіжного досвіду роботи з іноземними студентами. 
Однак, проведений нами аналіз за зазначеними вище критеріями відбору закладів освіти дозволив констатувати, що не всі ЗВО України мають повноцінну систему акультураційної тріади, яка передбачає підготовку лінгвістичного, культурного та психологічного характеру. Помилкові заходи навчальних закладів (наприклад, Мукачівського державного університету, Тернопільського національного економічного університету тощо) полягають у тому, що при підготовці іноземного студента тільки за одним напрямом або тільки використовуючи акультураційну діаду (з будь-яким поєднанням: лінгвістика-психологія, культура-лінгвістика тощо) неможливо повноцінно підготувати особистість до протидії впливу культурного шоку. Часто також спостерігається відстороненість психологічної служби як окремого структурного підрозділу навчального закладу, хоча психологічна підтримка повинна бути частиною акультураційного процесу. Тому відзначимо, що перспективним напрямом розвитку української адаптаційної системи $є$ розвиток Центрів підтримки іноземних студентів, які повинні передбачати три необхідні компоненти підготовчого процесу.

Наступним аспектом організаційного елементу виступає проведення інформаційноконсультаційної роботи з потенційними студентами з інших країн. Так, однією з організацій, що координує таку діяльність у США, виступає Асоціація міжнародних працівників освіти (NAFSA) [16]. Зазначимо, що при дослідженні адаптаційної інфраструктури українських ЗВО ми виявили активну роботу навчальних закладів, а також Центрів підготовки іноземних студентів. Проте перспективи розвитку такої діяльності повинні бути спрямовані на підвищення рівня використання міжнародного (зростання чисельності конференцій, участь у більшій кількості програм з обміну студентами та викладачами тощо) та інформаційного (більш активне використання сучасних інформаційних засобів, у тому числі розвиток сайтів навчальних закладів, активна робота офіційних сторінок у соціальних мережах, що дозволить збільшити загальне число потенційних студентів, які отримають необхідну інформацію. У цьому контексті необхідно підкреслити, що багато ЗВО України, в тому числі педагогічних (наприклад, Національний педагогічний університет імені М.П. Драгоманова [17], Дрогобицький державний педагогічний університет імені Івана Франка [18], Центральноукраїнський державний педагогічний університет імені Володимира Винниченка [19] та ін.), не мають на своїх сайтах достатньої інформації щодо роботи з іноземними студентами (розклад занять підготовчого етапу, тематика підготовчих програм тощо) або такого роду інформація є дуже обмеженою та не дозволяє потенційним студентам з інших країн оцінити рівень навчального закладу щодо адаптаційної роботи та проаналізувати види діяльності, які застосовуються при адаптаційній підготовці. Приміром, американські університети та коледжі (наприклад, Університет Алабами [20], [21]; Каліфорнійський університет в Лос-Анджелесі [22]; коледж Санта Моніка [23]; Єльський університет [24] та ін.), надають структуровану інформаційну складову, що дозволяє визначити, як і за допомогою якої діяльності проводяться адаптаційні заходи і, відповідно, оцінити якість процесу соціально-педагогічного супроводу.

Відповідно, ми приходимо до висновку про необхідність розвитку інформаційної складової Відділів міжнародних зв'язків та роботи з іноземними студентами в українських ЗВО як одного з важливих компонентів системи супроводу. Якщо іноземний студент буде впевнений у тому, що підготовча система навчального закладу забезпечить проведення якісного процесу подолання культурного шоку (отримавши достатню кількість інформації щодо програми підготовки та її результатів за допомогою текстових та візуальних засобів), він остаточно обере цей заклад освіти для вступу, що є своєрідним компонентом профорієнтаційної роботи. Проте, наше дослідження дає підставу зробити висновок, що більш розгалужену інформаційну складову іноземні студенти можуть отримати в навчальних закладах України, які є технічно-спрямованими, що демонструє недостатню інформаційно-просвітницьку роботу педагогічних закладів. Тому перспективним напрямом розвитку національної системи підтримки іноземних студентів є модернізація інформаційної міжнародної діяльності саме педагогічними університетами. 
Окрім того, організаційний елемент складається, в тому числі, з міжнародних організацій, які можуть надавати також освітні послуги, розвиваючи, таким чином, систему роботи з іноземними студентами та впроваджуючи отриманий досвід до ЗВО своєї країни. Так, прикладом можуть слугувати американські ініціативи «Корпус миру» [25], «Табір Америка» [26], «Програма з обміну майбутніми лідерами» (FLEX) [27] тощо. Особливістю всіх проєктів такого роду є можливість проведення практичного дослідження ефективності того чи іншого методу навчання та роботи з представниками різних культур i, у підсумку, виявлення найбільш якісних методів підготовки для подальшого впровадження.

Проте необхідно розуміти, що не тільки нормативно-правовий та організаційноконсультаційний елементи відіграють важливу роль у розвитку системи адаптаційної підготовки іноземних студентів. Важливим елементом виділяємо адаптаційно-освітній, що складається з трьох складових частин, а саме: психологічної підтримки, а також культурноспрямованої та лінгвістичної підготовки.

Підготовка до комунікаційної взаємодії спрямована на розвиток здатності іноземного студента взаємодіяти з представниками країни, яка приймає, та іншими іноземними студентами у межах академічного та соціального процесів.

У цілому підготовка до міжособистісної комунікації має певні труднощі у мотивуванні, тому виникає питання про те, як залучити іноземного студента до подальшого адаптаційного процесу, особливо після отримання ним достатніх навичок комунікації початкового або середнього рівня, які можуть бути сприйняті ним як достатні для подальшого академічного процесу, проте підготовча програма (як загальна, так і індивідуальна) може свідчити про необхідність проведення додаткових занять. У такому випадку на перший план виходить діяльність уже не викладачів, а працівників консультаційного центру (саме тому, перспективним напрямом розвитку української системи соціально-педагогічного супроводу є створення саме професійних консультаційних центрів, які повинні спеціалізуватися виключно на роботі з іноземними студентами, тому що співпраця з такими студентами кураторів груп (що $є$ актуальним для українських 3ВО) не може повноцінно замінити професійного консультанта. У такому випадку виникає питання про підготовку таких консультантів під час участі у програмах академічного обміну між українськими та іноземними навчальними закладами та при залученні до практичної діяльності в українських міжнародно-спрямованих освітньо-консультаційних організаціях, де вони можуть отримати досвід безпосередньої роботи з іноземними студентами в інших країнах (прикладами можуть слугувати такі організації та програми, як Програма Фулбрайта, Корпус миру тощо). Тому знову повертаємося до висновку про необхідність подальшого практичного впровадження таких програм в Україні, адже тільки в цьому випадку можна буде стверджувати про можливість формування цілісної та взаємодоповнюючої адаптаційної інфраструктури. У підсумку можемо констатувати, що всі елементи соціально-педагогічного супроводу є взаємопов'язаними, тому відсутність або недостатнє функціонування одного з елементів негативно відображається на функціонуванні всієї системи, чия робота може бути ефективною лише у випадку, якщо сам студент буде зацікавлений в адаптації до нового культурного середовища. Такі центри повинні сприяти прояву прагнення особистості до подолання адаптаційних етапів, навіть у випадку, якщо студент «зачиняється» внаслідок негативного впливу культурного шоку. У такому випадку важливо, для початку, встановити контакт необхідного рівня між консультантом та студентом, а потім, коли останній буде підготовлений до акультурації, почати реалізацію підготовчої програми на практиці.

У разі, якщо в іноземного студента відсутнє прагнення до подальшої адаптації, то немає сенсу у соціально-педагогічному супроводі, тому що адаптаційні заходи не дадуть належного результату. Тому консультант, можливо із залученням допомоги відділу з психологічної підтримки, повинен мотивувати іноземного студента до необхідності адаптації, у тому числі поясненнями важливості цього процесу для ефективної соціальної та академічної діяльно- 
сті. Також важливим є розуміння студентом, що адаптація надасть можливість формування додаткових навичок та компетентностей, придбання нового життєвого досвіду, - усе це позитивно вплине на розвиток його професійно-спрямованих якостей. Зазначимо, що більшість українських 3ВО (серед яких ХНУ ім. В.Н. Каразіна [28]; Полтавський державний аграрний університет [29], [30], [31]; Кременчуцький національний університет ім. Михайла Остроградського [32] та ін.) проводять загальну підготовку (що складається з лінгвістичної та соціокультурної адаптації) одночасно з професійною підготовкою за обраним іноземним студентом напрямом навчання. У такому випадку викладачі/консультанти отримують більше інструментів для мотивування студентів, акцентуючи на неможливості професійного розвитку без наявності якісно розвинених мовленнєвих навичок. Отже, такий спосіб мотивування можемо назвати професійно-спрямованим.

Також необхідно зазначити, що Центри підтримки іноземних студентів є консультаційноінформаційними, а сам процес інформування іноземних студентів повинен бути чітко вибудуваним. Насамперед важливо розуміти, що усе це передбачає надання іноземному студентові необхідної інформації щодо проблем, які будуть впливати на процес адаптації, а також у післяадаптаційний період. Тому перспективним напрямом роботи з іноземними студентами $є$ постійне вдосконалення методів інформування, які б забезпечили максимально якісне надання інформації про різні аспекти академічної та адаптаційної діяльності в навчальному закладі.

Щодо перспектив розвитку лінгвістичної підготовчої системи українських ЗВО, необхідно звернути увагу на важливість використання у підготовчих матеріалах спрямованості на всі чотири компоненти (говоріння, аудіювання, читання, письмо), що забезпечують повноцінне вивчення мови.

Лінгвістичний напрям підготовки формує необхідні навички, що дозволять проводити якісно вибудований комунікативний процес та повноцінно використовувати лінгвокультурні шаблони. Вважаємо за необхідне виділити лінгвістичну підготовку у ХНУ ім. В.Н. Каразіна [33], що представлена основними лінгвістичними компонентами, які є основою для розробки всього підготовчого комплексу, тобто всі теоретичні матеріали, вправи, а також заходи щодо практичного закріплення раніше отриманих знань повинні розроблятися з акцентом на говоріння, аудіювання, читання, письмо.

Розробки, наприклад, Кременчуцького національного університету ім. Михайла Остроградського [32], Запорізького національного університету [34] дають підстави висновковувати про спрямованість, більшою мірою, на оволодіння іноземними студентами загальними граматичними правилами української мови. Водночас необхідно зауважити, що завдання для підготовчих програм мають передбачати більш активне використання компоненту аудіювання, що дозволяє іноземним студентам розуміти отриману інформацію усного характеру.

Відзначимо також недостатність або повну відсутність у програмах з лінгвістичної підготовки українських 3ВО тематик для розвитку компоненту говоріння. Не зважаючи на те, що навчальні заклади та Центри підтримки іноземних студентів можуть змінювати формулювання тематик для розвитку говоріння, важливо розуміти загальну тематичну спрямованість, яка дозволить визначити, чи сприяють означені теми розвитку міжособистісного спілкування в тих напрямах, які є актуальними саме для іноземних студентів. Так, наприклад, іноземному студенту більш актуальна тематична ситуація «Похід до магазину» на відміну від ситуації «Розповідь про улюбленого літературного героя». Необхідно розуміти важливість формулювання тем для розвитку говоріння, які повинні враховувати, перш за все, повсякденні ситуації, що в них студенту необхідно буде взаємодіяти з громадянами країни, до якої вони прибули на навчання.

Отже, можна виділити основний аспект лінгвістичної підготовки іноземних студентів у ЗВО України, що потребує подальшого розвитку, а саме необхідність використання у підготовчих програмах з розвитку мовних навичок усіх чотирьох компонентів лінгвістичного 
процесу: говоріння, аудіювання, читання, писемної діяльності $i$, відповідно, розробка усіх завдань та вправ на основі цих чотирьох компонентів.

Висновки і перспективи подальших досліджень. Організаційний елемент системи соціально-педагогічного супроводу іноземних студентів має перспективи для подальшого розвитку у межах ЗВО України за такими напрямами:

- створення координаційно-консультаційного центру, який повинен виконувати не тільки функції управління національною системою супроводу іноземних громадян, але і проводити необхідну дослідницьку діяльність, що дозволить отримувати систематизовану статистичну інформацію про поточний стан адаптаційних процесів у ЗВО України, а також (базуючись на цих даних), проводити подальше вивчення зарубіжного досвіду, для упровадження позитивних аспектів до національної системи супроводу;

- розвиток Центрів підтримки іноземних студентів на базі закладів вищої освіти як структурних підрозділів, які здійснюють підготовку, використовуючи, для цього, акультураційну тріаду, що припускає одночасну підготовку до подолання культурного шоку (соціокультурний компонент), розвитку здатності комунікаційної взаємодії (лінгвістичний компонент), надання психологічного консультування (психологічний компонент);

- розвиток системи інформаційно-консультаційної підтримки, спрямованої на підвищення інформованості потенційних іноземних студентів про навчальний заклад, у тому числі використовуючи сучасні способи передачі інформації, а також можливості наукової діяльності та програм академічного обміну;

- створення та підтримка міжнародних організацій, які будуть сприяти просуванню української освітньої системи, а також практично впроваджувати методи підготовки та роботи з іноземними студентами, що згодом можуть бути застосовані у роботі 3ВО всередині країни.

- Своєю чергою адаптаційно-освітній елемент розвитку системи адаптаційної підготовки іноземного студента характеризується:

- наданням психологічної підтримки, що повинна складатися з мотивування особистості і заходів щодо подолання внутрішньоособистісних проблем, пов'язаних із культурним шоком;

- ознайомлення з культурними особливостями одночасно з розвитком мовних навичок (у чотирьох основних напрямах - говоріння, читання, аудіювання та письмова діяльність), що дозволить сформувати відповідні лінгвокультурні шаблони та ефективно взаємодіяти в академічному і соціальному середовищі іншокультурного соціуму.

Перспективними напрямами подальших наукових досліджень уважаємо проведення порівняльної характеристики за кожним елементом акультураційної тріади серед американських, європейських та українських ЗВО, в яких навчається найбільша кількість іноземних студентів.

\section{Використані джерела}

[1] Global Flow of Tertiary-Level Students. UNESCO. [Online]. Available: http://uis.unesco.org/en/uis-studentflow. Accessed on: March 26, 2020.

[2] C. Haddal, Foreign Students in the United States: Policies and Legislation. Washington, DC: Congressional Research Service, 2006.

[3] V. Clifford, and C. Montgomery, «Transformative learning through internationalization of the curriculum in higher education», Journal of Transformative Education, 13(1), pp. 46-64, 2015. https://doi. org/10.1177\%2F1541344614560909

[4] S. N. Berdan, A. Goodman, and C. Taylor, A student guide to study abroad. New York, NY: Institute of International Education, 2013. 
[5] N. Harrison, «Practice, problems and power in «internationalisation at home»: Critical reflections on recent research evidence», Teaching in Higher Education, 20(4), pp. 412-430, 2015. https://doi.org/10.1080/13562 517.2015.1022147

[6] S. F. Faleel, C.L. Tam, T.H. Lee, and W.M. Har, «Stress, perceived social support, coping capability and depression: A study of local and foreign students in the Malaysian context», International Journal of Social and Human Sciences, 61, pp. 75-81, 2012.

[7] О.М. Білик, «Теорія та методика соціалізації іноземних студентів в освітньо-культурному середовищі вищого навчального закладу», дис. д-ра пед. наук, Харків, 2018.

[8] О. Білик, «Соціально-педагогічний супровід соціалізації іноземних студентів в освітньо-культурному середовищі вищого навчального закладу», Вісник Черкаського університету, 5, с. 18-24, 2016.

[9] Л. Гармаш, «Шляхи оптимізації інтелектуального потенціалу студентів-першокурсників при адаптації до навчального процесу в ВНЗ», Актуальні проблеми психології. Психологія навчання. Медична психологія, т. 10, вип. 13, с. 101-109, 2009.

[10] В.С. Коломієць, «Формування професійних мовленнєвих умінь у студентів іноземного походження засобами комплексних дидактичних ігор», дис. канд. пед. наук, Київ, 2001.

[11] М. Максимець, «Формування соціокультурної компетенції у процесі вивчення іноземної мови», Вісник Львівського університету, Серія педагогічна, 21, с. 211-218, 2006.

[12] ноземні студенти в Україні. Український державний центр міжнародної освіти. [Електронний ресурс]. Доступно: https://studyinukraine.gov.ua/zhittya-v-ukraini/inozemni-studenti-v-ukraini/. Дата звернення: Лип. 06, 2021.

[13] Study in Ukraine. Український державний центр міжнародної освіти. [Електронний ресурс]. Доступно: https://studyinukraine.gov.ua/. Дата звернення: Лип. 06, 2021.

[14] Навчально-науковий інститут міжнародної освіти. ХНУ ім. В.Н. Каразіна. [Електронний ресурс]. Доступно: http://www-center.univer.kharkov.ua/index_ua.php. Дата звернення: Бер. 20, 2020.

[15] Institute of International Education. [Online]. Available: https://www.iie.org/. Accessed on: July 06, 2021.

[16] NAFSA: Association of International Educators. [Online]. Available: http://www.nafsa.org/About_Us/ About_NAFSA/History/The_History_of_NAFSA_Association_of_International_Educators/.Accessed on: July 06, 2021.

[17] Навчання іноземців. Національний педагогічний університет ім. М.П. Драгоманова. [Електронний ресурс]. Доступно: https://npu.edu.ua/osvita/navchannia-inozemtsiv\#reiestratsiia-na-kursy. Дата звернення: Лип. 06, 2021.

[18] Дрогобицький державний педагогічний університет ім. Івана Франка. [Електронний ресурс]. Доступно: http://dspu.edu.ua/. Дата звернення: Лип. 06, 2021.

[19] Навчання іноземних громадян. Центральноукраїнський державний педагогічний університет ім. Володимира Винниченка. [Електронний ресурс]. Доступно: https://www.cuspu.edu.ua/ua/an-entrantof-the-department-of-international-education/navchannia-inozemnykh-hromadian. Дата звернення: Лип. 06, 2021.

[20] About the English Language Institute (ELI). Capstone International Center. The University of Alabama. [Online]. Available: http://international.ua.edu/eli/about/. Accessed on: July 06, 2021.

[21] Capstone International Center. The University of Alabama. [Online]. Available: http://international.ua.edu/ educationabroad/. Accessed on: July 06, 2021.

[22] International Admission. University of California (UCLA). [Online]. Available: https://www.ucla.edu/admission/international-admission. Accessed on: July 06, 2021.

[23] International Education Center. Santa Monica College. [Online]. Available: https://www.smc.edu/studentsupport/international-education/. Accessed on: July 06, 2021.

[24] Office of International Students \& Scholars. Yale University. [Online]. Available: https://oiss.yale.edu/programsevents/annual-events/understanding-america. Accessed on: July 06, 2021.

[25] Peace Corps. Education. [Online]. Available: https://files.peacecorps.gov/multimedia/pdf/learn/whatvol/ onesheets/onesheets_education.pdf?_ga=2.66373806.1608859334.1625582741-1927975356.1625582741. Accessed on: July 06, 2021.

[26] Camp America. Vision, Mission, Values. [Online]. Available: https://www.campamerica.com/values.asp. Accessed on: July 06, 2021. 
[27] Future Leaders Exchange Program (FLEX). [Online]. Available: https://www.discoverflex.org/. Accessed on: July 06, 2021.

[28] Робоча програма дисципліни «Українська мова». Харків: Харківський національний університет імені В.Н. Каразіна, 2018, 14 с.

[29] Навчальний процес центру підготовки іноземних громадян. Полтавський державний аграрний університет. [Електронний ресурс]. Доступно: https://www.pdaa.edu.ua/content/navchalnyy-proces-centrupidgotovky-inozemnyh-gromadyan. Дата звернення: Бер. 25, 2021.

[30] Організаційно-виховна робота ЦПІГ. Полтавський державний аграрний університет. [Електронний ресурс]. Доступно: https://www.pdaa.edu.ua/content/organizaciyno-vyhovna-robota-cpig. Дата звернення: Бер. 25, 2021.

[31] Факультет підготовки іноземних громадян. Полтавський державний аграрний університет. [Електронний ресурс]. Доступно: https://www.youtube.com/watch?time_continue=85\&v=0kJ1cNV_39g\&feature=emb_title. Дата звернення: Бер. 25, 2021.

[32] Ц Центр підвищення кваліфікації та професійної адаптації. Кременчуцький національний університет імені Михайла Остроградського. [Електронний ресурс]. Доступно: http://www.kdu.edu.ua/new/fpk.php. Дата звернення: Бер. 25, 2020.

[33] Кафедра мовної підготовки 2. Головна. Навчально-науковий інститут міжнародної освіти. ХНУ ім. В.Н. Каразіна. [Електронний ресурс]. Доступно: http://www-center.univer.kharkov.ua/ukrrus/ua/ukrrus. php. Дата звернення: Бер. 25, 2020.

[34] Положення про центр освітніх послуг для іноземних громадян Запорізького національного університету. Запоріжжя, 2019.

\section{References}

[1] Global Flow of Tertiary-Level Students. UNESCO. [Online]. Available: http://uis.unesco.org/en/uis-studentflow. Accessed on: March 26, 2020. (in English)

[2] C. Haddal, Foreign Students in the United States: Policies and Legislation. Washington, DC: Congressional Research Service, 2006. (in English)

[3] V. Clifford, and C. Montgomery, «Transformative learning through internationalization of the curriculum in higher education», Journal of Transformative Education, 13(1), pp. 46-64, 2015. (in English)

[4] S. N. Berdan, A. Goodman, and C. Taylor, A student guide to study abroad. New York, NY: Institute of International Education, 2013. (in English)

[5] N. Harrison, «Practice, problems and power in «internationalisation at home»: Critical reflections on recent research evidence», Teaching in Higher Education, 20(4), pp. 412-430, 2015. (in English)

[6] S.F. Faleel, C. L. Tam, T.H. Lee, and W.M. Har, «Stress, perceived social support, coping capability and depression: A study of local and foreign students in the Malaysian context», International Journal of Social and Human Sciences, 61, pp. 75-81, 2012. (in English)

[7] O.M. Bilyk, «Theory and methods of foreign students' socialization in the educational and cultural environment of higher educational institution», M.S. thesis, Kharkiv, 2018. (in Ukrainian)

[8] O. Bilyk, «Social and Pedagogical Support of International Students' Socialization in the Framework of Universities' Educational and Cultural Environment», Visnyk Cherkaskoho universytetu, 5, s. 18-24, 2016. (in Ukrainian)

[9] L. Harmash, «The ways of intellectual potential optimization of first-year students during the adaptation to the educational process in HEI», Aktualni problemy psykholohii. Psykholohiia navchannia. Medychna psykholohiia, t. 10, vyp. 13, s. 101-109, 2009. (in Ukrainian)

[10] V.S. Kolomiiets, «Formation of foreign students’ professional speech skills by means of complex didactic games», M.S. thesis, Kyiv, 2001. (in Ukrainian)

[11] M. Maksymets, «Formation of socio-cultural competence in the process of foreign language learning». Visnyk Lvivskoho universytetu. Seriia pedahohichna, 21, s. 211-218, 2006. (in Ukrainian)

[12] International students in Ukraine. State Enterprise «Ukrainian State Center for International Education». [Online]. Available: https://studyinukraine.gov.ua/zhittya-v-ukraini/inozemni-studenti-v-ukraini/. Accessed on: July 06, 2021. (in Ukrainian) 
[13] Study in Ukraine. State Enterprise «Ukrainian State Center for International Education». [Online]. Available: https://studyinukraine.gov.ua/. Accessed on: July 06, 2021. (in Ukrainian)

[14] Institute of International Education for study and Research. V.N. Karazin Kharkiv National Uneversity. [Online]. Available: http://www-center.univer.kharkov.ua/index_ua.php. Accessed on: March 20, 2020. (in Ukrainian)

[15] Institute of International Education. [Online]. Available: https://www.iie.org/. Accessed on: July 06, 2021. (in English)

[16] NAFSA: Association of International Educators. [Online]. Available: http://www.nafsa.org/About_Us/ About_NAFSA/History/The_History_of_NAFSA_Association_of_International_Educators/. Accessed on: July 06, 2021. (in English)

[17] Foreigners’ Training. National Pedagogical Dragomanov University. [Online]. Available: https://npu.edu.ua/ osvita/navchannia-inozemtsiv\#reiestratsiia-na-kursy. Accessed on: July 06, 2021. (in Ukrainian)

[18] Drohobych Ivan Franko State Pedagogical University. [Online]. Available: http://dspu.edu.ua/. Accessed on: July 06, 2021. (in Ukrainian)

[19] Training of foreign citizens. Volodymyr Vynnychenko Central Ukrainian State Pedagogical University. [Online]. Available: https://www.cuspu.edu.ua/ua/an-entrant-of-the-department-of-international-education/ navchannia-inozemnykh-hromadian. Accessed on: July 06, 2021. (in Ukrainian)

[20] About the English Language Institute (ELI). Capstone International Center. The University of Alabama. [Online]. Available: http://international.ua.edu/eli/about/. Accessed on: July 06, 2021. (in English)

[21] Capstone International Center. The University of Alabama. [Online]. Available: http://international.ua.edu/ educationabroad/. Accessed on: July 06, 2021. (in English)

[22] International Admission. University of California (UCLA). [Online]. Available: https://www.ucla.edu/admission/international-admission. Accessed on: July 06, 2021. (in English)

[23] International Education Center. Santa Monica College. [Online]. Available: https://www.smc.edu/studentsupport/international-education/. Accessed on: July 06, 2021. (in English)

[24] Office of International Students \& Scholars. Yale University. [Online]. Available: https://oiss.yale.edu/programsevents/annual-events/understanding-america. Accessed on: July 06, 2021. (in English)

[25] Peace Corps. Education. [Online]. Available: https://files.peacecorps.gov/multimedia/pdf/learn/whatvol/ onesheets/onesheets_education.pdf?_ga=2.66373806.1608859334.1625582741-1927975356.1625582741. Accessed on: July 06, 2021. (in English)

[26] Camp America. Vision, Mission, Values. [Online]. Available: https://www.campamerica.com/values.asp. Accessed on: July 06, 2021. (in English)

[27] Future Leaders Exchange Program (FLEX). [Online]. Available: https://www.discoverflex.org/. Accessed on: July 06, 2021. (in English)

[28] Work program of the discipline «Ukrainian language». Kharkiv: V.N. Karazin Kharkiv National Uneversity, 2018. (in Ukrainian)

[29] Study Process in the Center of International education. Poltava State Agrarian University. Available: https://www. pdaa.edu.ua/content/navchalnyy-proces-centru-pidgotovky-inozemnyh-gromadyan. Accessed on: March 25, 2021. (in Ukrainian)

[30] Organizational and Educational Work in the Center of International Education. Poltava State Agrarian University. [Online]. Available: https://www.pdaa.edu.ua/content/organizaciyno-vyhovna-robota-cpig. Accessed on: March 25, 2021. (in Ukrainian)

[31] Faculty of foreign citizens' training. Poltava State Agrarian University. [Online]. Available: https://www. youtube.com/watch?time_continue=85\&v=0kJ1cNV_39g\&feature=emb_title. Accessed on: March 25, 2021. (in Ukrainian)

[32] Center for advanced training and professional adaptation. Kremenchuk Mykhailo Ostrohradskyi National University. [Online]. Available: http://www.kdu.edu.ua/new/fpk.php. Accessed on: March 25, 2020. (in Ukrainian)

[33] The Department of Ukrainian and Russian as Foreign Languages. Main. Institute of International Education for study and Research. V.N. Karazin Kharkiv National Uneversity. [Online]. Available: http://www-center. univer.kharkov.ua/ukrrus/ua/ukrrus.php. Accessed on: March 25, 2020. (in Ukrainian)

[34] Regulations on the center of educational services for foreign citizens of Zaporizhzhia National University. Zaporizhzhia, 2019. (in Ukrainian) 
Yaroslav Slutskyi, PhD (Pedagogy), Donbas State College of Technology and Management, Toretsk, Doctoral student of Donbas State Pedagogical University, Sloviansk.

\section{PERSPECTIVE DIRECTIONS OF DEVELOPMENT \\ OF THE FOREIGN STUDENTS' TRAINING ADAPTATION SYSTEM \\ IN UKRAINIAN HIGHER EDUCATION INSTITUTIONS}

This paper presents the current situation and identifies the perspective directions of development of foreign students' adaptive training system in the Higher Educational Institutions (HEI) of Ukraine. The organizational and adaptive-educational elements of adaptation are highlighted. The comparative characteristics of Ukrainian and American HEIs in the issue of carrying out adaptation measures were used, which allowed to identify perspective areas that require an active implementation of the system of foreign students' training in domestic educational institutions.

The organizational element of the system of foreign students' social and pedagogical support has prospects for further development within the HEIs of Ukraine in the following areas:

- creation of a coordination and consultation center, which will allow to receive a systematized statistical information about the current condition of adaptation processes in the HEIs of Ukraine, and carry out a further study of foreign experience to include positive aspects to the national student's support system;

- development of Support Centers for Foreign Students on the basis of HEIs as structural units that provide training; use for this aim the acculturation triad, that involves a simultaneous training for culture shock overcoming (sociocultural component), development of communication skills (linguistic component), providing psychological counseling (psychological component);

- creation and support of internationally-oriented organizations that will promote the Ukrainian educational system, as well as practically implement the methods of training and working with foreign students, that can later be used in the work HEIs within the country.

- At the same time, the adaptive-educational component of the development of the system of foreign students' adaptive training is characterized by:

- providing psychological support, that should consist of personal motivation and measures to overcome the intrapersonal problems associated with the impact of culture shock;

- awareness of the cultural features combined with the development of language skills (in four main areas - speaking, reading, listening and writing), that will form appropriate linguistic and cultural patterns that will effectively interact in the academic and social environment of the host society.

Key words: research and analytical activity; organizational and consulting functions; acculturation dyad / triad; socio-pedagogical support. 